\title{
Blockade of D-2 Dopamine Receptors Strongly Enhances the Potency of Enkephalins to Inhibit Dopamine-Sensitive Adenylate Cyclase in Rat Neostriatum: Involvement of $\delta$ - and $\mu$-Opioid Receptors
}

\author{
Anton N. M. Schoffelmeer, ${ }^{*}$ Hakon A. Hansen, $\dagger$ Johannes C. Stoof, $\dagger$ and Arie H. Mulder \\ *Department of Pharmacology and †Department of Neurology, Free University, Medical Faculty, \\ 1081 BT Amsterdam, The Netherlands
}

\begin{abstract}
The interactions between dopamine receptors and opioid receptors coupled to adenylate cyclase in rat neostriatum were investigated. cAMP efflux from neostriatal slices induced by simultaneous activation of (stimulatory) D-1 and (inhibitory) D-2 dopamine receptors with $30 \mu \mathrm{M}$ dopamine was inhibited by the preferential $\delta$-opioid receptor agonist $\left[\mathrm{D}-\mathrm{Ala}^{2}-\mathrm{D}-\mathrm{Leu}^{5}\right]$ enkephalin (DADLE) and the $\mu$-opioid receptor agonist morphine with an $\mathrm{EC}_{50}$ of 100 and $800 \mathrm{nM}$, respectively. On selective D-1 receptor activation (i.e., with D-2 receptors blocked by $10 \mu \mathrm{M}$ (-)sulpiride), the $\mathrm{EC}_{50}$ of DADLE was strongly reduced to 3 nM, whereas that of morphine was unaffected. When D-1 and D-2 receptors were activated simultaneously, the inhibitory effects of DADLE $(0.3 \mu \mathrm{M})$ and morphine $(3 \mu \mathrm{M})$ on cAMP efflux were antagonized equally well by naloxone, a $\mu$-opioid receptor antagonist. In contrast, on selective $D-1$ receptor activation, naloxone was about 20 times more potent in antagonizing the inhibitory effect of morphine than DADLE. Moreover, the $\delta$-opioid receptor antagonist ICI $174864(0.75 \mu \mathrm{M})$ did not affect the inhibitory effect of morphine but antagonized that of DADLE, provided that D-2 receptors were blocked. The highly selective $\delta$-opioid receptor agonist [n-Pen $\left.{ }^{2}-\mathrm{D}-\mathrm{Pen}^{5}\right]$ enkephalin (DPDPE) inhibited dopamine-stimulated cAMP efflux only when D-2 receptors were blocked. Similar results were obtained when the agonists SKF 38393 and LY 141865 were used to activate D-1 and D-2 receptors, respectively.

These data indicate that blockade of $D-2$ receptors in the neostriatum elicits the coupling of $\delta$-opioid receptors to dopamine-sensitive adenylate cyclase, thereby making it considerably more sensitive to inhibition by the enkephalins.
\end{abstract}

Opioid receptors in peripheral tissues and in the CNS can be distinguished pharmacologically in at least 3 different typesviz., $\mu$ (morphine), $\delta$ (enkephalin), and $\kappa$ (benzomorphan/dynorphin) receptors - but the functional implications of this receptor multiplicity are still largely unknown (Chang et al., 1981; Gillan and Kosterlitz, 1982; Lord et al., 1977; Martin, 1984; Mulder et al., 1984; Paterson et al., 1983; Wood, 1982; Wüster et al., 1981). The neostriatum, the major target region for information transmitted by dopaminergic neurons arising from the substantia nigra (Dray, 1979), contains a large number of enkephalinergic neurons (Cuello, 1983; Hughes et al., 1977; Yang et al., 1977), as well as a high density of opioid receptors, particularly those of the $\delta$ - and $\mu$-types (Atweh and Kuhar, 1983; Wamsley,

\footnotetext{
Received Sept. 30, 1985; revised Jan. 23, 1986; accepted Jan. 24, 1986.

Correspondence should be addressed to Anton N. M. Schoffelmeer, Department of Pharmacology, Free University, Medical Faculty, van der Boechorstraat 7, 1081 BT Amsterdam, The Netherlands.

Copyright (C) 1986 Society for Neuroscience $0270-6474 / 86 / 082235-05 \$ 02.00 / 0$
}

1983). A variety of circumstantial evidence suggests that modulation of dopaminergic neurotransmission plays a role in the action of opioids on the CNS (Chesselet et al., 1981; Hirschhorn et al., 1983; Iwamato and Way, 1979; Mulder et al., 1984; Wood, 1983) and may, in fact, also be one of the functional consequences of release of endogenous opioid peptides.

In the neostriatum, 2 pharmacologically and functionally different types of dopamine receptors have been demonstrated, i.e., D-1 and D-2 (Creese et al., 1983; Kebabian and Calne, 1979; Seeman, 1980; Stoof and Kebabian, 1981). Activation of D-1 receptors results in an increase in cAMP formation, whereas this effect is partially antagonized by simultaneous activation of D-2 receptors, which apparently are coupled to adenylate cyclase in an inhibitory way (Stoof and Kebabian, 1981, 1982). Recently, it has been reported that in neostriatal homogenates the increase in cAMP formation induced by $D-1$ receptor activation is also partially inhibited by activation of $\delta$-opioid receptors (Bowen et al., 1981; Gentleman et al., 1983). However, homogenization of brain tissue may result in a disruption of the coupling of some receptors-such as $\beta$-adrenoceptors (Kebabian et al., 1972), D-2 receptors (J. C. Stoof, unpublished observations), and possibly $\mu$-opioid receptors - to adenylate cyclase.

In the present study, neostriatal slices instead of homogenates were used as a more intact tissue preparation to explore the effects of selective activation of either $\delta$ - or $\mu$-opioid receptors on the dopamine receptor-regulated cAMP formation. Simultaneous activation of D-1 and D-2 receptors was effected by dopamine and selective activation of $\mathrm{D}-1$ receptors by dopamine in the presence of $(-)$ sulpiride, a selective D-2 receptor antagonist (Stoof and Kebabian, 1981, 1982).

\section{Materials and Methods}

\section{Preparation and superfusion of neostriatal slices}

Male Wistar rats (200-240 gm body weight) were killed by decapitation and their brains rapidly removed. Two $2 \mathrm{~mm}$ thick coronal slices between anterior planes A 5300 and A 9300 (König and Klippel, 1970) of the neostriatum were prepared and cut into smaller slices $(2 \times 0.3 \times$ $0.3 \mathrm{~mm}$ ) using a McIlwain tissue chopper. The slices were washed twice with $10 \mathrm{ml} \mathrm{Krebs-Ringer} \mathrm{bicarbonate} \mathrm{medium} \mathrm{containing} 121 \mathrm{~mm} \mathrm{NaCl}$, $1.87 \mathrm{mM} \mathrm{KCl}, 1.17 \mathrm{mM} \mathrm{KH} \mathrm{PO}_{4}, 1.17 \mathrm{mM} \mathrm{MgSO}_{4}, 1.22 \mathrm{mM} \mathrm{CaCl}, 25$ $\mathrm{mm} \mathrm{NaHCO}$, and $10 \mathrm{~mm} \mathrm{D(+)-glucose.} \mathrm{In} \mathrm{addition,} \mathrm{the} \mathrm{medium} \mathrm{con-}$ tained $1 \mathrm{~mm}$ 3-isobutyl-1-methylxanthine in order to prevent breakdown of AMP by phosphodiesterase. After washing, the slices were transferred to each of 24 chambers of a superfusion apparatus $(0.3 \mathrm{ml}$ volume, $20 \mathrm{mg}$ of tissue/chamber) and subsequently superfused $(0.1$ $\mathrm{ml} / \mathrm{min}$ ) with medium, kept under an atmosphcre of $95 \% \mathrm{O}_{2}$ and $5 \%$ $\mathrm{CO}_{2}$, at $37^{\circ} \mathrm{C}$. After $60 \mathrm{~min}$ of superfusion $(t=60 \mathrm{~min})$, a $20 \mathrm{~min}$ basal efflux fraction was collected. Drugs were added at $t=80 \mathrm{~min}$ and a second $20 \mathrm{~min}$ fraction was collected from between 100 and $120 \mathrm{~min}$. 


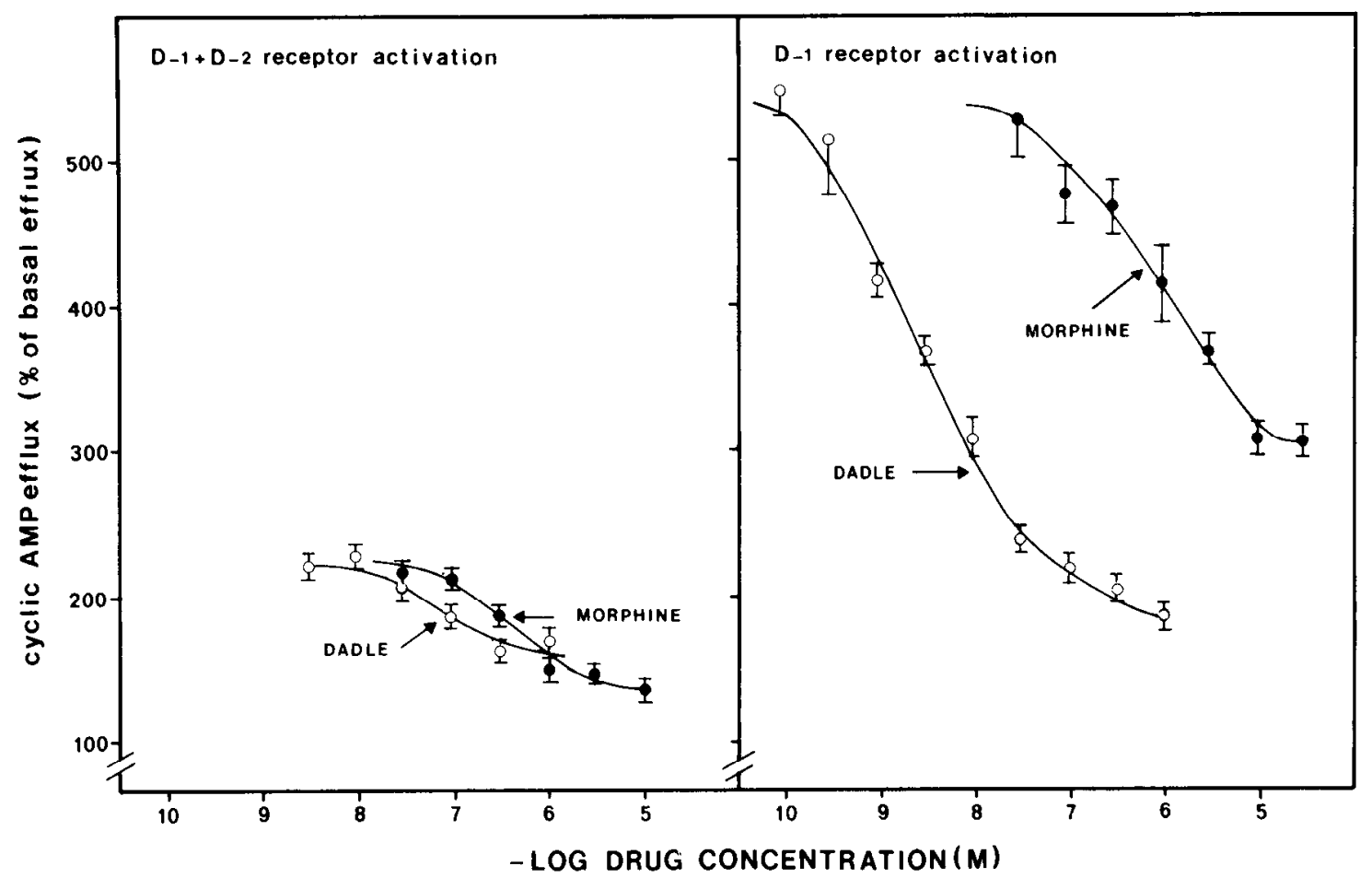

Figure 1. Effects of the selective $\delta$-opioid receptor agonist DADLE and the $\mu$-opioid receptor agonist morphine on cAMP efflux induced by 30 $\mu \mathrm{M}$ dopamine in the absence (D-1 + D-2 receptor activation) or presence (D-1 receptor activation) of $10 \mu \mathrm{M}(-)$ sulpiride. Slices were superfused and after $60 \mathrm{~min}$, a $20 \mathrm{~min}$ basal efflux fraction was collected. Drugs were added at $t=80 \mathrm{~min}$, and a second 20 min fraction was collected between 100 and $120 \mathrm{~min}$. cAMP content of the first (basal) fraction amounted to $22.4 \pm 1 \mathrm{fmol} / \mathrm{min}$. Data, expressed as the percentage increase in cAMP content of the second fraction relative to the first, represent means \pm SEM of 12-16 observations. In each experiment, quadruplicate observations were made.

\section{Determination of drug effects}

The cAMP content of triplicate $100 \mu$ l aliquots of the first and the second fractions was estimated using a radioimmunoassay (Brooker et al., 1979). The limit of detection of this assay is $5.0 \mathrm{fmol} / 100 \mu$ l. Since preliminary experiments showed that the cAMP content determined in the second fraction did not differ $(96 \pm 3.8 \%, n=12)$ from that in the first, and the latter varied between experiments (from $8.8 \pm 0.5$ to $38.4 \pm 0.9$ $\mathrm{fmol} / \mathrm{min}$ ), drug effects were expressed as the percentage increase in cAMP content of the second fraction relative to the first. The statistical significance of differences was determined by the 2-tailed Student's $t$ test.

\section{Drugs}

The following drugs were obtained commercially: [D-Ala $\left.{ }^{2}-\mathrm{D}-\mathrm{Leu}^{5}\right]$ enkephalin (DADLE), dopamine hydrochloride, and 3-isobutyl-1-meth-

Table 1. Effect of $(+)$ and $(-)$ sulpiride on the inhibition of dopamine-stimulated cAMP efflux by DADLE

cAMP efflux ( $\%$ basal efflux) induced by:

\begin{tabular}{llll}
$\begin{array}{l}\text { DADLE } \\
\text { conc. } \\
(\mu \mathrm{M})\end{array}$ & $30 \mu \mathrm{M}$ dopamine & $\begin{array}{l}30 \mu \mathrm{M} \text { dopa- } \\
\text { mine }+10 \mu \mathrm{M} \\
(+) \text { sulpiride }\end{array}$ & $\begin{array}{l}30 \mu \mathrm{M} \text { dopa- } \\
\text { mine }+10 \mu \mathrm{M} \\
(-) \text { sulpiride }\end{array}$ \\
\hline 0 & $217 \pm 6$ & $221 \pm 5$ & $548 \pm 13$ \\
0.03 & $226 \pm 8$ & $217 \pm 6$ & $274 \pm 6^{*}$ \\
0.3 & $149 \pm 4^{*}$ & $142 \pm 5^{*}$ & $212 \pm 8^{*}$
\end{tabular}

Slices were superfused and after $60 \mathrm{~min}$ a $20 \mathrm{~min}$ basal efflux fraction was collected. Drugs were added at $t=80 \mathrm{~min}$ and a second $20 \mathrm{~min}$ fraction was collected from $t=100-120 \mathrm{~min}$. The cAMP content of the first (basal) fraction amounted to $21.6 \pm 0.8 \mathrm{fmol} / \mathrm{min}$. Drug effects were expressed as percentage increase in cAMP content of the second fraction relative to the first. Data represent means \pm SEM of 12 observations. In each experiment, quadruplicate observations were made. ${ }^{*} p<0.01$ compared to cAMP efflux in the absence of DADLE. ylxanthine (Sigma). SKF 38393 was a gift from Smith, Kline \& French, LY 141865 from Eli Lilly, (-)sulpiride from Delagrange, (+)sulpiride from Ravizza, and ICI 174864 frorn Imperial Chemical Industries. [D-Pen ${ }^{2}-\mathrm{D}-\mathrm{Pen}^{5}$ ] enkephalin (DPDPE) and the cAMP antibody were

Table 2. Effects of different opioids on dopamine-stimulated cAMP efflux in the absence and presence of the selective $\delta$-opioid receptor antagonist ICI 174864

\begin{tabular}{lcl} 
& \multicolumn{2}{c}{ cAMP efflux (\% of control) } \\
\cline { 2 - 3 } Drugs & $\begin{array}{l}\text { D-1 }+ \text { D-2 } \\
\text { receptor } \\
\text { activation }\end{array}$ & $\begin{array}{l}\text { D-1 receptor } \\
\text { activation }\end{array}$ \\
\hline $0.03 \mu \mathrm{M}$ DADLE & $96 \pm 3$ & $48 \pm 3$ \\
$+0.75 \mu \mathrm{M}$ ICI 174864 & $103 \pm 4$ & $98 \pm 4^{*}$ \\
$0.3 \mu \mathrm{M}$ DADLE & $51 \pm 2$ & $32 \pm 2$ \\
$+0.75 \mu \mathrm{M}$ ICI 174864 & $54 \pm 4$ & $56 \pm 4^{*}$ \\
$3.0 \mu \mathrm{M}$ morphine & $54 \pm 3$ & $56 \pm 5$ \\
$+0.75 \mu \mathrm{M}$ ICI 174864 & $48 \pm 2$ & $51 \pm 3$ \\
$0.3 \mu \mathrm{M}$ DPDPE & $103 \pm 4$ & $38 \pm 2$ \\
$+0.75 \mu \mathrm{M}$ ICI 174864 & - & $59 \pm 6^{*}$
\end{tabular}

Slices were superfused and after $60 \mathrm{~min}$ a $20 \mathrm{~min}$ basal efflux fraction was collected. Drugs were added at $t=80 \mathrm{~min}$ and a second $20 \mathrm{~min}$ fraction was collected between 100 and 120 min. cAMP content of the first (basal) fraction amounted to $16.7 \pm 0.6 \mathrm{fmol} / \mathrm{min}$. Control cAMP efflux (determined in the second fraction) in the presence of $30 \mu \mathrm{M}$ dopamine alone (D-1 + D-2 receptor activation) amounted to $222 \pm 8 \%$ of basal efflux and $579 \pm 14 \%$ on addition of $10 \mu \mathrm{M}(-)$ sulpiride (D-1 receptor activation). ICI 174864 by itself did not affect cAMP efflux. Data, given as the percentage of control cAMP efflux, are means \pm SEM of 8-12 observations. In each experiment, quadruplicate observations were made. ${ }^{*} p<$ 0.01 compared to inhibition in the absence of ICI 174864 . 


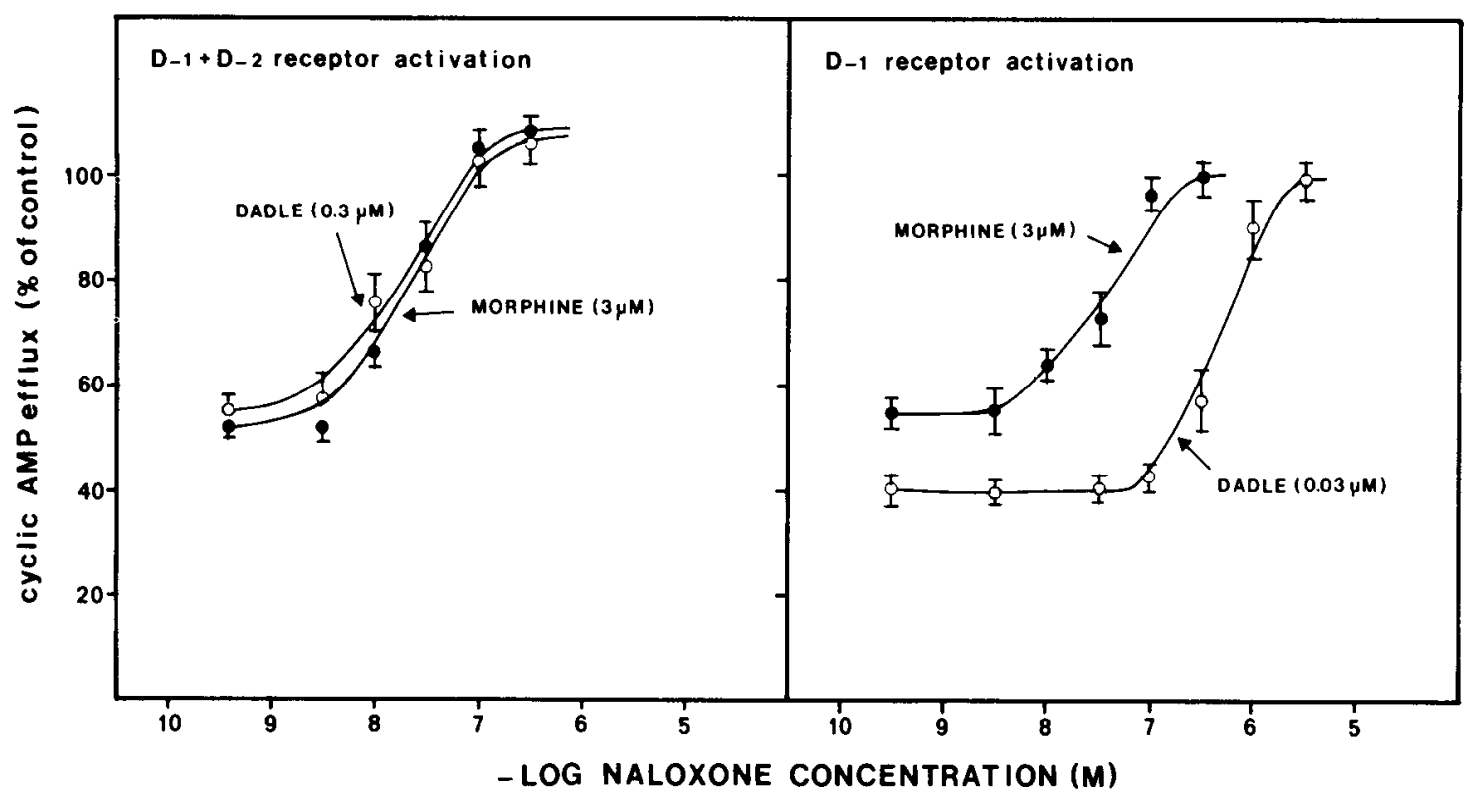

Figure 2. Antagonism by naloxone of the inhibitory effects of DADLE and morphinc on cAMP efflux induced by $30 \mu \mathrm{M}$ dopamine in the absence $(\mathrm{D}-1+\mathrm{D}-2$ receptor activation) and presence (D-1 receptor activation) of $10 \mu \mathrm{M}(-)$ sulpiride. Slices were superfused and after $60 \mathrm{~min}$, a $20 \mathrm{~min}$ basal efflux fraction was collected. Drugs were added at $t=80 \mathrm{~min}$, and a second $20 \mathrm{~min}$ fraction was collected between 100 and $120 \mathrm{~min}$. The cAMP content of the first (basal) fraction amounted to $17.3 \pm 0.8 \mathrm{fmol} / \mathrm{min}$. Control cAMP efflux (determined in the second fraction) in the presence of dopamine alone amounted to $236 \pm 6 \%$ of basal efflux and to $588 \pm 12 \%$ on addition of $(-)$ sulpiride. Data, given as the percentage of control cAMP efflux, are means \pm SEM of 8-12 observations. In each experiment, quadruplicate observations were made.

kindly donated by Dr. V. J. Hruby (University of Arizona, Tucson) and Dr. G. Brooker (Georgetown University, Washington, D.C.), respectively.

\section{Results}

\section{Inhibition of dopamine-sensitive adenylate}

\section{cyclase by opioid receptor agonists}

When neostriatal slices were exposed to $30 \mu \mathrm{M}$ dopamine, the efflux of cAMP was approximately doubled. Both DADLE and morphine reduced the increase in cAMP efflux in a concentration-dependent fashion, with an $\mathrm{EC}_{50}$ of about 100 and $800 \mathrm{nM}$, respectively. Blockade of the D-2 receptors by $10 \mu \mathrm{M}(-)$ sulpiride strongly enhanced the response of the slices to $30 \mu \mathrm{M}$ dopamine, which now caused an approximately 6-fold increase of the cAMP efflux. Also under these conditions, both morphine and DADLE inhibited the increase in cAMP efflux in a concentration-dependent fashion. However, whereas blockade of D-2 receptors did not affect the $\mathrm{EC}_{50}$ of morphine, that of DADLE was greatly reduced (to about $3 \mathrm{nM}$ ) (Fig. 1). In the presence of $10 \mu \mathrm{M}(+)$ sulpiride, the cAMP efflux induced by $30 \mu \mathrm{M}$ dopamine was not inhibited by DADLE at concentrations up to 30 nM (Table 1). The $\delta$-opioid receptor agonist DPDPE $(0.3 \mu \mathrm{M})$ inhibited dopamine-stimulated cAMP efflux in the presence, but not in the absence, of (-)sulpiride (Table 2).

\section{Effects of the $\mu$ - and $\delta$-opivid receptor antagonists naloxone and ICI 174864}

When D-1 and D-2 receptors were activated simultaneously by $30 \mu \mathrm{M}$ dopamine, the inhibitory effects of near maximally effective concentrations of morphine $(3 \mu \mathrm{M})$ and DADLE $(0.3 \mu \mathrm{M})$ on cAMP efflux were antagonized equally well by naloxone. In contrast, on selective D-1 receptor stimulation (i.e., with D-2 receptors blocked), naloxone was about 20 times more potent in antagonizing the inhibitory effect of morphine $(3 \mu \mathrm{M})$ than that of DADLE $(0.03 \mu \mathrm{M})$ (Fig. 2). In fact, $0.1 \mu \mathrm{M}$ naloxone appeared to discriminate between the effects of morphine and DADLE in this case (Fig. 2). The inhibitory effects of morphine
(3 $\mu \mathrm{M})$ were not affected by ICI 174864 at a concentration of $0.75 \mu \mathrm{M}$. However, whereas the inhibitory effect of DADLE on cAMP efflux induced by $30 \mu \mathrm{M}$ dopamine remained unchanged in the presence of ICI 174864, this drug strongly antagonized the inhibitory effect of DADLE when D-2 receptors were blocked (Table 2). The inhibitory effect of DPDPE $(0.3 \mu \mathrm{M})$ on cAMP efflux induced by selective D-1 receptor activation was also significantly antagonized by ICI 174864 (Table 2).

Table 3. Opioid receptor-mediated inhibition of cAMP efflux induced by the selective D-1 receptor agonist SKF 38393 and the effect of the selective D-2 receptor agonist I.Y 141865 thereon

\begin{tabular}{|c|c|c|}
\hline \multirow[b]{2}{*}{ Drugs } & \multicolumn{2}{|c|}{$\begin{array}{l}\text { cAMP efflux (\% of control) } \\
\text { in the presence of: }\end{array}$} \\
\hline & $\begin{array}{l}10 \mu \mathrm{M} \text { SKF } \\
38393\end{array}$ & $\begin{array}{l}10 \mu \mathrm{M} \text { SKF } \\
38393+3.0 \\
\mu \mathrm{M} \text { LY } 141865\end{array}$ \\
\hline $\begin{array}{l}0.03 \mu \mathrm{M} \text { DADLE } \\
\quad+0.1 \mu \mathrm{M} \text { naloxone }\end{array}$ & $\begin{array}{l}52 \pm 6 \\
56 \pm 4\end{array}$ & $\begin{array}{c}98 \pm 4 \\
-\end{array}$ \\
\hline $\begin{array}{l}0.3 \mu \mathrm{M} \text { DADLE } \\
\quad+0.1 \mu \mathrm{M} \text { naloxone }\end{array}$ & $\begin{array}{l}41 \pm 4 \\
48 \pm 3\end{array}$ & $\begin{array}{c}54 \pm 4 \\
106 \pm 5^{*}\end{array}$ \\
\hline $\begin{array}{l}3.0 \mu \mathrm{M} \text { morphine } \\
\quad+0.1 \mu \mathrm{M} \text { naloxone }\end{array}$ & $\begin{array}{l}62 \pm 2 \\
97 \pm 6^{*}\end{array}$ & $\begin{array}{l}56 \pm 5 \\
94 \pm 3^{*}\end{array}$ \\
\hline $\begin{array}{l}0.3 \mu \mathrm{M} \text { DPDPE } \\
+0.1 \mu \mathrm{M} \text { naloxone }\end{array}$ & $\begin{array}{l}48 \pm 3 \\
46 \pm 5\end{array}$ & $\begin{array}{c}103 \pm 7 \\
-\end{array}$ \\
\hline
\end{tabular}

Slices were superfused and after $60 \mathrm{~min}$ a $20 \mathrm{~min}$ basal cfflux fraction was collected. Drugs were added at $t=80 \mathrm{~min}$ and a second 20 min fraction was collected between 100 and $120 \mathrm{~min}$. cAMP content of the first (basal) fraction amounted to $28.4 \pm 0.8 \mathrm{fmol} / \mathrm{min}$. Control cAMP efflux (determined in the second fraction) in the presence of SKF 38393 alone (D-1 receptor activation) amounted to 381 $\pm 11 \%$ of basal efflux and $208 \pm 7 \%$ in the presence of both SKF 38393 and LY 141865 (D-1 + D-2 receptor activation). Naloxone by itself did not affect cAMP efflux. Data given as the percentage of control cAMP efflux are means \pm SEM of 8 observations. ${ }^{*} p<0.01$ as compared to inhibition in the absence of naloxone. 
Opioid receptor-mediated inhibition of CAMP efflux induced by the selective $D-1$ receptor agonist

$S K F 38393$ and the effect of the selective

$D$-2 receptor agonist $L Y 141865$

Neostriatal slices exposed to $10 \mu \mathrm{M}$ SKF 38393 exhibited an almost 4-fold enhancement of cAMP efflux. The increase in cAMP efflux was strongly inhibited by 0.03 and $0.3 \mu \mathrm{M}$ DADLE, and this effect was not affected by $0.1 \mu \mathrm{M}$ naloxone. In the presence of $3 \mu \mathrm{M}$ LY 141865, SKF 38393 caused a more than 2-fold enhancement of cAMP efflux. In this case, the inhibitory effect of DADLE $(0.3 \mu \mathrm{M})$ on the stimulated cAMP efflux was fully antagonized by $0.1 \mu \mathrm{M}$ naloxone. The inhibitory effect of morphine $(3 \mu \mathrm{M})$ was antagonized by naloxone, independent of whether D-2 receptors were activated by LY 141865 or not. Finally, DPDPE $(0.3 \mu \mathrm{M})$ inhibited SKF 38393-induced cAMP efflux in the absence, but not in the presence, of LY 141865 (Table 3).

\section{Discussion}

The present study reveals that the involvement of different opioid receptor subtypes in the inhibitory effect of opioids on dopamine-sensitive adenylate cyclase in rat neostriatum is regulated by the activation of D-2 receptors. When D- 1 and D- 2 receptors were activated simultaneously by dopamine (Stoof and Kebabian, 1981), cAMP efflux was inhibited by the opioid receptor agonists DADLE and morphine, which display selectivity for $\delta$ - and $\mu$-opioid receptors, respectively (Martin, 1984; Paterson et al., 1983; Wüster et al., 1981). On selective activation of D1 receptors, i.e., with D-2 receptors blocked by $(-)$ sulpiride (Stoof and Kebabian, 1981), the $\mathrm{EC}_{50}$ of morphine (about 800 nM) was not affected, while that of DADLE was stongly reduced (from about 100 to $3 \mathrm{~nm}$ ). In order to exclude the possibility that this effect of $(-)$ sulpiride might not be related to $D-2$ receptor blockade, its inactive enantiomer, $(+)$ sulpiride, was also used. In this case, the cAMP efflux induced by dopamine was not inhibited by DADLE in concentrations up to $30 \mathrm{nM}$. Thus, it appears that blockade of D-2 receptors strongly enhances the potency of DADLE in inhibiting D-1 receptor-stimulated cAMP formation. To examine whether the shift in $\mathrm{EC}_{50}$ of DADLE reflects an interaction of DADLE with different opioid receptor subtypes, the antagonists naloxone and ICI 174864 were employed, which have selectivity for $\mu$ - and $\delta$-opioid receptors, respectively (Cotton et al., 1984; Hirning et al., 1985). It was observed that naloxone antagonized the inhibitory effect of DADLE and that of morphine equally well when D-1 and D-2 receptors were activated simultaneously, while with $D$-2 receptors blocked, naloxone was about 20 times more potent in antagonizing the inhibitory effect of morphine than that of DADLE. ICI 174864 did not affect the inhibitory effects of morphine on simultaneous D-1 and D-2 or selective D-1 receptor activation, whereas in the concentration used $(0.75 \mu \mathrm{M})$, it strongly antagonized the inhibition caused by DADLE, provided that $D-2$ receptors were blocked. The inhibitory effects of morphine and DADLE on cAMP efflux and the antagonistic potency of naloxone were similar when the (partial) agonists SKF 38393 and LY 141865 were used, which selectively activate D-1 and D-2 receptors, respectively (Stoof and Kebabian, 1981, 1982).

Together our findings strongly suggest that the opioid receptors mediating an inhibition of the cAMP efflux caused by simultaneous D-1 and D-2 receptor activation display exclusively $\mu$-opioid receptor selectivity. On the other hand, when D-2 receptors are blocked, the inhibitory effects of morphine and DADLE on the dopamine-induced efflux of cAMP appear to involve $\mu$ - and $\delta$-opioid receptors, respectively. This conclusion is further strengthened by the observation that the highly selective $\delta$-opioid receptor agonist DPDPE (Mosberg et al., 1983), which in contrast to DADLE has a very low affinity for $\mu$-opioid receptors (Akiyama et al., 1985; Hirning et al., 1985), inhibited the dopamine-induced cAMP efflux only when $\mathrm{D}-2$ receptors were blocked or when cAMP efflux was induced by SKF 38393 alone.

With regard to the molecular mechanisms underlying the phenomena described here, it is very likely that the modulatory receptor-mediated interactions occur at the level of adenylate cyclase, since it has been shown that on activation both opioid receptors (Abood et al., 1985; Cooper et al., 1982; Frey and Kebabian, 1984; Gentleman et al., 1983; Kurose et al., 1983; Law et al., 1981; West and Miller, 1983) and dopamine receptors (Cote et al., 1982; Creese et al., 1983; Kuno et al., 1983; Rodbell, 1980) may be coupled to the enzyme through guanine nucleotide regulatory proteins. It has been suggested that the opioid binding sites-designated as $\mu$-, $\delta$-, and $\kappa$-opioid receptors-correspond to seperate biochemical entities (Cho et al., 1983; Zajac and Roques, 1985) with different primary structures (Howard et al., 1985). Moreover, in view of the distinct (autoradiographic) localizations of $\mu$ - and $\delta$-opioid receptor binding sites in the neostriatum, with $\mu$-binding sites localized in patches (striosomes) and $\delta$-binding sites more homogeneously distributed (Herkenham and Pert, 1981; see also Graybiel et al., 1981), the functional $\mu$ - and $\delta$-opioid receptors investigated here may reside on different cells. Therefore, a possible explanation of our findings is that in cells containing both $\mathrm{D}-2$ receptors and $\delta$-opioid receptors, the receptors compete for the same inhibitory guanine regulatory proteins, whereas in other cells, containing $\mu$-opioid receptors, D-2 receptors are lacking. On the other hand, it has been suggested that $\mu$ - and $\delta$-opioid binding sites in striatal patches may be allosterically coupled and constitute an opioid receptor complex (Bowen et al., 1981; Rothman et al., 1985). If this latter hypothesis holds true for the $\mu$ - and $\delta$-opioid receptors negatively coupled to dopamine-sensitive adenylate cyclase, our data indicate that the pharmacological profile of such an opioid receptor complex might be regulated by activation of D-2 receptors.

Although the functional implications of cAMP formation induced by D-1 receptor activation and the inhibitory effects of opioids thereon remain enigmatic, the discovery that D-2 receptor blockade results in the appearance of (previously silent) functionally active $\delta$-opioid receptors, coupled to adenylate cyclase, is highly intriguing. In addition to the dense dopaminergic innervation, the neostriatum contains high levels of enkephalins (Cuello, 1983; Hughes et al., 1977; Yang et al., 1977). Like their metabolically stable congener DADLE, the endogenous enkephalins display a considerably higher affinity for $\delta$ - than for $\mu$ opioid receptors (Paterson et al., 1983). Therefore, blockade of D-2 receptors would rosult in a substantially enhanced sensitivity of D-1 receptor-stimulated adenylate cyclase to inhibition by enkephalins. It is tempting to speculate that this previously unknown consequence of D-2 receptor blockade is important for the antipsychotic action of neuroleptic drugs, which are thought to block primarily D-2 receptors in the CNS (Seeman, 1980; Snyder, 1984). Other studies have shown that neuroleptic treatment enhances enkephalin biosynthesis in the neostriatum (Hong et al., 1979) and induces behavioral supersensitivity to opioids (Stinus et al., 1985), also suggesting the involvement of endogenous opioids in the action of antipsychotic drugs.

\section{References}

Abood, M. E., P. Y. Law, and H. H. Loh (1985) Pertussis toxin treatment modifies opiate action in the ral striatum. Biochem. Biophys. Res. Commun. 127: 477-483.

Akiyama, K., K. W. Gee, H. I. Mosberg, V. J. Hruby, and H. I. Yamamura (1985) Characterization of $\left[{ }^{3} \mathrm{H}\right]$ [2-D-penicillamine, 5-Dpenicillamine]-enkephalin binding to $\delta$-opiate receptors in the rat brain and neuroblastoma-glioma hybrid cell line (NG 108-15). Proc. Natl. Acad. Sci. USA 82: 2543-2547. 
Atweh, S. F., and M. J. Kuhar (1983) Distribution and physiological significance of opioid receptors in the brain. Br. Med. Bull. 39:4752.

Bowen, W. D., S. Gentleman, M. Herkenham, and C. B. Pert (1981) Interconverting $\mu$ and $\delta$ forms of the opiate receptor in rat striatal patches. Proc. Natl. Acad. Sci. USA 78: 4818-4822.

Brooker, G., J. F. Harper, W. L. Terasaki, and R. D. Moylan (1979) Radioimmunoassay of cyclic AMP and cyclic GMP. Adv. Cyclic Nucleotide Res. 10: 1-33.

Chang, K.-J., E. Hazum, and P. Cuatrecasas (1981) Novel opiate binding sites selective for benzomorphan drugs. Proc. Natl. Acad. Sci. USA 78: 4141-4145.

Chesselet, M. F., A. Cheramy, T. D. Reisine, and J. Glowinski (1981) Morphine and $\delta$-opiate agonists locally stimulate in vivo dopamine release in cat caudate nucleus. Nature 291: 320-322.

Cho, T. M., B. L. Gee, C. Yamato, A. P. Smith, and H. H. Loh (1983) Isolation of opiate binding components by affinity chromatography and reconsitution of binding activities. Proc. Natl. Acad. Sci. USA 80: 5176-5180.

Cooper, D. M. F., C. Londos, D. L. Gill, and M. Rodbell (1982) Opiate receptor-mediated inhibition of adenylate cyclase in rat striatal plasma membranes. J. Neurochem. 38: 1164-1167.

Cote, T. E., R. L. Eskay, E. A. Frey, C. W. Grewe, M. Munemura, J. C. Stoof, K. Tsuruta, and J. W. Kebabian (1982) Biochemical and physiological studies of the beta-adrenoceptor and the D-2 dopamine receptor in the intermediate lobe of the rat pituitary gland: A review. Neuroendocrinology 35: 217-224.

Cotton, R., M. G. Giles, L. Miller, J. S. Shaw, and D. Timms (1984) ICI 174864: A highly selective antagonist for the opioid $\delta$-receptor. Eur. J. Pharmacol. 97: 331-332.

Creese, I., D. R. Sibley, M. W. Hamblin, and S. E. Leff (1983) The classification of dopamine receptors: Relationship to radioligand binding. Annu. Rev. Neurosci. 6: 43-71.

Cuello, A. C. (1983) Central distribution of opioid peptides. Br. Med. Bull. 39: 11-16.

Dray, A. (1979) The striatum and substantia nigra: A commentary on their relationship. Neuroscience 4: 1405-1439.

Frey, E. A., and J. W. Kebabian (1984) A $\mu$-opiate receptor in 7315c tumor tissue mediates inhibition of immunoreactive prolactin release and adenylate cyclase activity. Endocrinology 115: 1797-1804.

Gentleman, S., M. Parenti, N. H. Neff, and C. B. Pert (1983) Inhibition of dopamine-activated adenylate cyclase and dopamine binding by opiate receptors in rat striatum. Cell. Mol. Neurobiol. 3: 17-26.

Gillan, M. G. C., and H. W. Kosterlitz (1982) Spectrum of the $\mu$-, $\delta$ and $\kappa$-binding sites in homogenates of rat brain. Br. J. Pharmacol. 77: 461-469.

Graybiel, A. M., C. W. Ragsdale, E. S. Yoneoka, and R. P. Elde (1981) An immunohistochemical study of enkephalins and other neuropeptides in the striatum of the cat with evidence that the opiate peptides are arranged to form mosaic patterns in register with the striosomal compartments visible by acetylcholinesterase staining. Neuroscience 6: $377-397$

Herkenham, M., and C. B. Pert (1981) Mosaic distribution of opiate receptors parafascicular projections and acetylcholinesterase in rat striatum. Nature $291:$ : $15-418$.

Hirning, L. D., H. I. Mosberg, R. Hurst, V. J. Hruby, T. F. Burks, and F. Porreca (1985) Studies in vitro with ICI 174864, [D-Pen ${ }^{2}, \mathrm{D}-\mathrm{Pen}^{5}$ ]enkephalin (DPDPE) and [D-Ala ${ }^{2}, \mathrm{NMePhe}^{4}$, Gly-ol]-enkephalin (DAGO). Neuropeptides 5: 383-386.

Hirschhorn, I. D., D. Hittner, E. L. Gardner, J. Cubells, and M. H. Makman (1983) Evidence for a role of endogenous opioids in the nigrostriatal system: Influence of naloxone and morphine on nigrostriatal dopaminergic supersensitivity. Brain Res. 270: 109-117.

Hong, J. S., H.-Y. T. Yang, J. C. Gillin, A. M. Di Giulio, W. Fratta, and E. Costa (1979) Chronic treatment with haloperidol accelerates the biosynthesis of enkephalins in rat striatum. Brain Res. 160: 192195.

Howard, A. D., S. de La Baume, T. L. Gioannini, J. M. Hiller, and E. J. Simon (1985) Covalent labeling of opioid receptors with radioiodinated human $\beta$-endorphin. J. Biol. Chem. 260: 10833-10839.

Hughes, J., H. W. Kosterlitz, and T. W. Smith (1977) The distribution of methionine-enkephalin and leucine-enkephalin in the brain and peripheral tissues. Br. J. Pharmacol. 61: 639-647.

Iwamoto, E. T., and E. L. Way (1979) Opiate action and catecholamines. Adv. Biochem. Psychopharmacol. 20: 357-407.
Kebabian, J. W., and D. B. Calne (1979) Multiple receptors for dopamine. Nature 277: 93-96.

Kebabian, J. W., P. Petzold, and P. Greengard (1972) Dopaminesensitive adenylate cyclase in caudate nucleus of rat brain and its similarity to the "dopamine receptor." Proc. Natl. Acad. Sci. USA 69: 2145-2149.

König, J. F. R., and R. A. Klippel (1970) The Rat Brain, A Stereotaxic Atlas, Kreiger, New York.

Kuno, T., O. Shirakawa, and D. Tanaka (1983) Selective decrease in the affinity of $D_{2}$ dopamine receptor for agonist induced by isletactivating protein pertussis toxin, associated with ADP-ribosylation of the specific membrane protcin of bovine striatum. Biochem. Biophys. Res. Commun. 115: 325-330.

Kurose, H., T. Katada, T. Amano, and M. Ui (1983) Specific uncoupling by islet-activating protein, pertussis toxin, of negative signal transduction via $\alpha$-adrenergic, cholinergic and opiate receptors in neuroblastoma $\times$ glioma hybrid cells. J. Biol. Chem. 258: 4870-4875.

Law, P. Y., J. Wu, J. E. Koehler, and H. H. Loh (1981) Demonstration and characterization of opiate inhibition of the striatal adenylate cyclase. J. Neurochem. 36: 1834-1846.

Lord, J. A. H., A. A. Waterfield, J. Hughes, and H. W. Kosterlitz (1977) Endogenous opioid peptides: Multiple agonists and receptors. Nature 267: 495-499.

Martin, W. R. (1984) Pharmacology of opioids. Pharmacol. Rev. 35: 283-323.

Mosberg, H. I., R. Hurst, V. J. Hruby, K. Gec, H. I. Yamamura, J. J. Galligan, and T. F. Burks (1983) Bis-penicillamine enkephalins possess highly improved specificity toward $\delta$-opioid receptors. Proc. Natl. Acad. Sci. USA 80: 5871-5874.

Mulder, A. H., G. Wardeh, F. Hogenboom, and A. L. Frankhuyzen (1984) $\kappa$ - and $\delta$-opioid receptor agonists differentially inhibit striatal dopamine and acetylcholine release. Nature 308: 278-280.

Paterson, S. J., L. E. Robson, and H. W. Kosterlitz (1983) Classification of opioid receptors. Br. Med. Bull. 39: 31-36.

Rodbell, M. (1980) The role of hormone receptors and GTP-regulatory proteins in membrane transduction. Nature 284: 17-21.

Rothman, R. B., W. D. Bowen, M. Herkenham, A. E. Jacobson, K. C. Rice, and C. B. Pert (1985) A quantitative study of [ $\left.{ }^{3} \mathrm{H}\right]\left[\mathrm{D}-\mathrm{Ala}^{2}-\mathrm{D}-\right.$ $\mathrm{Leu}^{5}$ ]-enkephalin binding to rat brain membranes. Evidence that oxomorphine is a noncompetitive inhibitor of the lower affinity $\delta$-binding site. Mol. Pharmacol. 27: 399-408.

Seeman, P. (1980) Brain dopamine receptors. Pharmacol. Rev. 32: 229-313.

Snyder, S. H. (1984) Drug and neurotransmitter receptors in the brain. Science 224: 22-31.

Stinus, L., M. Winnock, and A. E. Kelley (1985) Chronic neuroleptic treatment and mesolimbic dopamine denervation induce behavioural supersensitivity to opiates. Psychopharmacology 85: 323-328.

Stoof, J. C., and J. W. Kebabian (1981) Opposing roles for D-1 and D-2 dopamine receptors in efflux of cyclic AMP from rat neostriatum. Nature 294: 366-368

Stoof, J. C., and J. W. Kebabian (1982) Independent in vitro regulation by the D-2 dopamine receptor of dopamine-stimulated efflux of cyclic AMP and $\mathrm{K}^{+}$-stimulated release of acetylcholine from rat neostriatum. Brain Res. 250: 263-270.

Wamsley, J. K. (1983) Opioid receptors: Autoradiography. Pharmacol. Rev. 35: 69-83.

West, R. E., and R. J. Miller (1983) Opiates, second messengers and cell response. Br. Med. Bull. 39: 53-58.

Wood, P. L. (1982) Multiple opiate receptors: Support for unique mu, delta and kappa sites. Neuropharmacology 21: 487-497.

Wood, P. L. (1983) Opioid regulation of CNS dopaminergic pathways: A review of methodology, receptor types, regional variations and species differences. Peptides 4: 595-601.

Wüster, M., R. Schulz, and A. Herz (1981) Multiple opiate receptors in peripheral tissue preparations. Biochem. Pharmacol. 30: 18831887.

Yang, H. Y., J. S. Hong, and E. Costa (1977) Regional distribution of leu- and met-enkephalin in rat brain. Neuropharmacology $16: 303-$ 307.

Zajac, J. M., and B. P. Roques (1985) Differences in binding properties of $\mu$ and $\delta$ opioid receptor subtypes from rat brain: Kinetic analysis and effects of ions and nucleotides. J. Neurochem. 44: 1605-1614. 